\title{
JOURNAL POLICY
}

The Journal of Paleontology publishes original articles on taxonomic paleontology and the implications of taxonomic paleontology to all aspects of paleobiology and stratigraphic paleontology. Comments on article and replies are considered for publication. Manuscripts should be submitted to the office of the Managing Editor, which handles the review process. The Technical Editors work with authors to produce final copy, and they return manuscripts to the Managing Editor for final processing. Manuscripts submitted elsewhere should not be submitted to the Journal.

Contributors should read the "Preparation of Manuscripts," below; more detailed "Instructions for Authors" were published in the January, 1995 issue (69:182-186). Manuscripts not adhering to format will be returned to authors for correction before entering the editorial process. Cost of Journal publication is taken entirely from membership dues in The Paleontological Society and voluntary page contributions. By action of the Council of the Society (Journal of Paleontology, 1985, 59:789), all publication costs for members will be covered by membership funds, although members are asked for voluntary contributions to defray costs. At least one author of a manuscript must be a member; nonmembers are required to pay full page costs. Editors use their judgement in setting aside the membership rule for individuals who can neither join the Society nor pay page charges. For new members (i.e., Society membership up to three months), the Society will provide eight published pages, but requires full page costs for papers in excess of eight pages in length. Authors are charged for changes they make in proof and for their original mistakes that must be corrected in proof. A limit of 25 published pages is placed on all papers within the Journal; limited excess pages might be accepted but their cost will be charged to the author. Longer manuscripts must be submitted to the memoir series; all publication costs for memoirs must be paid by authors.

\section{PREPARATION OF MANUSCRIPTS GENERAL}

Important references for format preparation are: 1) The Journal of Paleontology Instructions for Authors (Volume 69, pages 182186); 2) Suggestions to Authors of the Reports of the United States Geological Survey (seventh edition) 1991; and 3) The Chicago Manual of Style (fourteenth edition) 1993. Where there is conflict, current Journal style prevails; any recent issue provides a useful guide, but note changes with the 69:182-186 "Instructions for Authors."

All copy must be submitted on either $21.5 \times 28.0 \mathrm{~cm}\left(8 \frac{1}{2} \times 11\right.$ in.) or A4 standard-weight paper. Submit three copies. Manuscripts must be laser printed or letter-quality typed; dot-matrix printing is not acceptable. Avoid small font sizes; 12-point Times or 10-point Helvetica are appropriate. Double-space throughout, including references and table and figure descriptions; provide ample margins. Submitted copies need not include original illustrations, but they should be of very high quality; originals may be requested if submitted figures are not of adequate quality. Use metric measurements. A $7.5-10.0 \mathrm{~cm}$ heading is left on the first page above the title. First-page format should follow published examples.

\section{TEXT}

ABSTRACT - An abstract of 250 or fewer words is required for articles; abstracts do not accompany notes or other comments. The heading for the abstract is not indented; it is capitalized throughout, and it is followed by two hyphens but no period.

Headings.-Two grades of headings are almost always sufficient. Primary headings are centered and typed in all capital letters. Secondary headings are indented, underlined, and followed by a period and two hyphens. The first two words of the introduction are capitalized and abut the left margin. Do not end manuscript lines with hyphens.

Systematics.-Format for arrangement of systematic paleontology can be found in current issues of the Journal. All descriptions of new taxa must be accompanied by a diagnosis, an indication of type specimens and repository, stratigraphic and geographic data, and specific reference to illustrations of the taxon. Particularly note the format, punctuation, and capitalization conventions used in the synonymy.

\section{REFERENCES}

Particular care should be given to reference format. The "Instructions for Authors" provides many examples, but note that certain minor stylistic changes were initiated with the 69(1) issue.

\section{ILLUSTRATIONS}

Figures.-All illustrations, including maps, geologic sections, and halftone illustrations, must be numbered in the sequence of their first appearance in the text. "Figure" is used rather than "Plate," and therefore line drawing and photographic figures are numbered in sequence. All illustrations, including review copies, must be submitted at publication size. These sizes are: full page, $18.3 \times 23.3 \mathrm{~cm}$; double-column, $18.3 \mathrm{~cm}$; single column, $9.0 \mathrm{~cm}$. Halftone illustrations must be original photographs mounted on black or white cardboard. Photographic subjects must be illuminated from the upper left, or evenly illuminated. A photograph of a montage is not acceptable. Each illustration must be identified by a numeral, but typewritten numbering is not acceptable. Presson lettering is acceptable, but it readily breaks from the original and therefore much care must be used. Line drawings may be either an original or a glossy print mounted on white cardboard. Allow $1.5 \mathrm{~cm}$ at top of figure for a printer's label. Color photocopies of photographs provide superior reproduction and should be used for review. 


\title{
PALEONTOLOGICAL SOCIETY TOPICAL PUBLICATIONS
}

The Society's topical publications, which are still in print, are listed. These include presentations at short courses held at the Society's annual meeting, proceedings of symposia, and other events sponsored by the Society. Individual and library rates are the same.

\section{Short Courses Notes:}

Mammals_-organized by P.D. Gingerich and C.E. Badgley (1984), 234 p., \$12.

Mollusks — organized by D.J. Bottjer, C.S. Hickman, and P.D. Ward (1985), 308 p., \$12.

Land Plants-organized by R.A. Gastaldo (1986), 226 p., \$12.

Fossil Prokaryotes and Protists—organized by J.H. Lipps (1987), 303 p., $\$ 5$.

\section{Short Courses in Paleontology:}

Molecular Evolution and the Fossil Record—organized by Bruce Runnegar and J.W. Schopf (1988), 167 p., \$12.

The Age of Dinosaurs—organized by Kevin Padian and Daniel J. Chure (1989), 210 p., \$15.

Arthropod Paleobiology—organized by D.L. Mikulic (1990), 312 p., $\$ 15$.

Analytical Paleobiology—organized and edited by N.L. Gilinsky and P.W. Signor (1991), 216 p., \$15.

Trace Fossils—organized and edited by C. G. Maples and R. R. West (1992), 236 p., \$15.

Taphonomic Approaches to Time Resolution in Fossil Assemblages-organized and edited by S.M. Kidwell and A.K. Behrensmeyer (1993), 302 p., \$15.

Major Features of Vertebrate Evolution—organized and edited by D. R. Prothero and R. M. Schoch (1994), 270 p., \$15.

\section{Special Publications:}

Volume 1: The Evolution-Creation Controversy: Perspectives on Religion, Science, and Education-A Handbook. Organized by R.A. Gastaldo and W.F. Tanner (1984), 154 p., $\$ 7$.

Volume 2: Paleoecology and Taphonomy of Pleistocene to Recent Intertidal Deposits, Gulf of California. K.W. Flessa (ed.) (1987), 240 p., \$5.

Volume 3: Methods and Applications of Plant Paleoecology. W.A. DiMichele and S.L. Wing (eds.) (1988), 171 p., \$5.

Volume 4: Paleotechniques. R.M. Feldmann, R.E. Chapman, and J.T. Hannibal (eds.) (1989), 358 p., $\$ 20$.

Volume 5: Paleocommunity Temporal Dynamics: The Long-term Development of Multispecies Assemblages. W. Miller, III (ed.) (1990), 421 p., $\$ 15$.

Volume 6: Fifth North American Paleontological Convention-Abstracts and Program. S. Lidgard and P.R. Crane (eds.) (1992), 329 p., \$20.

Volume 7: Dino Fest. G. D. Rosenberg and D. L. Wolberg (eds.) (1994), 503 p., \$30.

Volume 8: 6th North American Paleontological Convention Abstracts of Papers. J.E. Repetski (ed.)(1996), 443p., \$5.

\section{Paleontological Society Papers:}

Volume 1: Paleobiology and Biology of Corals. G.D. Stanley, Jr. (ed.) (1996) \$20.

Volume 2: Learning From the Fossil Record. J. Scotchmoor and F.K. McKinney (eds.) (1996) \$20.

Volume 3: Geobiology of Echinoderms. J.A. Waters and C.G. Maples (eds.) (1997) \$20.

Send mail orders to:

\author{
Paleontological Society Topical Publications \\ Division of Earth Sciences \\ Carnegie Museum of Natural History \\ 4400 Forbes Ave. \\ Pittsburgh, PA 15213-4080
}

A check or institutional purchase order must accompany the order. Payment is to be made in \$US to The Paleontological Society. Orders will be shipped 4th class mail; orders outside of North America add \$2 US for surface mail.

(NOTE: Communications about the JOURnal should be addressed to: Journal of PALEONTOLOGY Subscriptions Office, P.O. Box 1897, 810 East 10th St., Lawrence, KS 660448897.) 